\title{
Trend Analysis of Students' Academic Performance in Selected Science, Technology, Engineering, and Mathematics Subjects in Ogun State Basic Education Certificate Examination (OG-BECE), Nigeria, from 2011 to 2015: A Projection for Five Years
}

\author{
Peter Abayomi Onanuga*, Adewale 0. Saka \\ Department of Science and Technology Education, Faculty of Education, Olabisi Onabanjo University, Ago-Iwoye, Ogun State, Nigeria \\ *Corresponding author: pierrenuga@gmail.com
}

\section{ABSTRACT}

The study investigated the trend of performance of students in selected Science, Technology, Engineering, and Mathematics (STEM) subjects in the Basic Education Certificate Examination (BECE) conducted by Ogun State Ministry of Education, Science and Technology, Nigeria. The study adopted an ex post facto research design to carry out the trend analysis of students' results in the examination from 2011 to 2015. All the students that enrolled and sat for the BECE examinations constituted the target population while the students that sat for the selected STEM subjects (Mathematics, Basic Science, and Basic Technology) within the years under review constituted the sample for the study. The results of these students were collected and analyzed using Microsoft Excel with its in-built trend line capabilities. The results showed that students performed well in the selected STEM subjects in the years under review. Furthermore, the study revealed that while performance in other subjects will continue to improve steadily, performance in mathematics will dwindle between 2016 and 2018 and then will begin to steadily improve from 2019 to 2020. It is recommended that the government should continue to support teaching and learning of STEM subjects in all tiers of education.

KEY WORDS: trend analysis, academic performance; science, technology; engineering; and mathematics subjects

\section{INTRODUCTION}

^ oday's society is characterized by an increasing rate of complex changes, uncertainties, challenges, and problems (Barnett and Coat, 2005; Jackson, 2005) requiring individuals to possess certain skills. It is a society full of disorders, complexities, and ambiguities with environmental, social, political, and economic pressures. The labor market is also dynamically competitive, demanding employees who can successfully meet workplace challenges, innovate, act quickly, and present effective solutions to problems yet unknown. This type of society encourages the learners to possess creativity, collaboration, communication, and critical thinking skills, which have been described as the $21^{\text {st }}$ century skills, to be able to cope and contribute positively to the society.

Meanwhile, the development of any nation has been linked to its scientific and technological development. According to Adikwu (2012), any nation that wants to experience economic growth must have strong commitment toward science. This implies that science plays a significant role in the economic, technological, political, and environmental development of any nation because science has permeated all facets of human life. However, there have been global calls for a paradigm shift from the disciplinary approach to teaching and learning Science, Technology, Engineering, and Mathematics (STEM) to interdisciplinary and multidisciplinary approach of integrating the four disciplines into one cohesive discipline called STEM education to show the interconnectedness among the various disciplines and how the skills acquired could be used in the real world.

Ndinechi and Okafor (2016) describe STEM education as a global concept that encompasses the process of critical thinking, analysis, and collaboration in which students integrate the process and concept in the real world. It is a global initiative with intent to enhance economic prosperity through a highly educated workforce (Science Ambassador Foundation [SAF], 2014). It is pivotal to the technological development and progresses of any nation (Umoh, 2016), and students need a strong foundation in these subjects to be able to function properly in the $21^{\text {st }}$ century (Salau, 2017). The United Nations Educational, Scientific, and Cultural Organization (UNESCO, 2016) stated that STEM fields are crucial for sustainable development because they help in finding solutions to threats posed by global challenges such as climate change, global health epidemics, and increased income inequality. This implies that effective STEM education is capable of inculcating in learners the skills that will enable them to function effectively in the modern-day society, which has been described as knowledge driven by many nations including Nigeria. 
Since the inclusion of the concept of STEM education in the various school curricula, many acronyms have been coined to reflect the number of disciplines that actually constitute to the concept. Such acronyms include but not limited to Science, Technology, and Mathematics, STEM, Science, Technology, Engineering, Art, and Mathematics, Science, Technology, Mathematics, and Computer, Modified-Science, Technology, and Mathematics, and Science, Technology, Engineering, Reading, Art, and Mathematics. However, there is concurrence among the different authors that there was integration of different disciplines into one cohesive discipline as reflected in all of the names coined. This study, therefore, adopted the use of STEM education.

The Florida Department of Education (FDE, 2017) observed that STEM education has contributed to every aspect of our lives because science is everywhere in the world around us and it is continuously expanding. It illuminates the ever more complex issues that govern the future of our democracy, and it reveals to us the beauty and power of the world (SAF, 2014). In the submission of Obomanu and Adaramola (2011), effective STEM education is essential for all students to enable them to appreciate the goals of STEM education in shaping and defining their common life history and culture. It also enables them to acquire appropriate skills and competencies that will inspire them to contribute meaningfully to the development of society. Shameema and Christian (2017) also observed that today's tools will be outdated as new technologies emerge, and it is, therefore, vital to impart STEM-capable skills to students to enable them to adapt any tools of the future.

Portz (2015) argues that the purpose of STEM education is to take advantage of the critical skills inherent in the subjects that make up the STEM when they are integrated into real-world applications by modeling the way they are used in the industry. Similarly, Shameema and Christian (2017) also stressed that STEM education is important due to its incorporation of the technology that affects humans' day-to-day activities. It makes basic scholars, builds science literacy, and empowers the up and coming era of "trendsetters." Igboanugo and Egolum (2017) stated that the purpose of STEM education is to produce learners who are creative, analytical, and rational as well as the acquisition of STEM skills that should lead to empowerment in some general sense of citizens for decision-making ability in the society.

Experience has shown that in some of the schools, especially in Nigeria where STEM subjects are taught, they do so in a disjointed manner contrary to the multidisciplinary approach being advocated. In many schools, STEM education concentrated heavily on science and mathematics at the expense of the critical roles of engineering and technology in preparing students to participate in an increasingly digital world (English, 2015). Positive experiences in upper basic education will facilitate students' future engagement in STEM subjects. Unfortunately, many students who indicate an interest in STEM subjects in secondary schools do so to boost their chances of qualification for tertiary education (McDonald, 2016). This means that they will only take STEM subjects to acquire the competencies required for qualifying examinations into the tertiary institutions after which they will drop these subjects. However, job markets need individuals with STEMcapable skills that can solve problems, come up with the ideas, and have an engineering mindset (i.e., creativity).

The Next Generation Science Standards (NGSS, 2013) stressed that the integration of STEM subjects is to assist students to make connections with concepts, applications, and disciplines. The NGSS stipulate that students should not be presented with instruction, leading to one performance expectation in isolation because bundles of performances provide greater coherence and allow students to see the connected nature of science and practice. Similarly, Matazu and Julius (2017) stressed that the fundamental goal of an integration approach to STEM education is to inculcate scientific values, and this requires coordination of both knowledge and skills simultaneously including entrepreneurial skills. Comino (2017) opined that the intentional integration of the disciplines is essential for the development of critical thinking, creativity, engineering design process, and problem-solving skills.

According to the National Research Council (NRC, 2014), advocates of subject integration argue that teaching STEM subjects in a more integrated way, especially in the context of real world issues can make these fields more relevant to students and ultimately increase their motivation and achievement. McDonald (2016) corroborated that argument when he advocated that an authentic STEM education is expected to build students' conceptual knowledge of the interrelatedness nature of science and mathematics to allow them to develop their understanding of engineering and technology. However, it has also been observed that students do not naturally assimilate concepts across different representations and materials on their own and requested that the proponent of integrated STEM experience should provide intentional and explicit support to help students build knowledge and skills within and across disciplines (NRC, 2014). The NRC, while noting that such support is either missing or not explicitly stated, that teacher education programmes should assist educators to make connections among the the different subjects that make up STEM eduction in order to appreciate the importance of the integration.

It is obvious from the foregoing that STEM skills are some of the $21^{\text {st }}$ century skills, which students need to be able to solve various societal problems. However, students make decisions about their participation in STEM careers at the secondary level of education and have the ability to decide whether or not they will pursue STEM-related disciplines later in life (McDonald, 2016). As many subjects are prerequisites for future study in tertiary institutions, students who decide not to study STEM-related disciplines have fewer opportunities to be engaged in society as STEM professionals (Ainley et al., 2008). This means that students who elect not to appreciate the values of STEM by offering subjects in STEM-related areas may have difficulty living and contributing positively to society because the STEM-literacy skills would elude such individuals. According to the European University Association 
(2007), the complex problems of the future will not be solved by "books" but by creative, forward-looking individuals, and groups who are not afraid to ask questions and are ready to face the consequences of their actions. These are the skills inherent in effective STEM education.

Reports have shown that governments are committed to the realization of the goals of STEM education by embarking on several initiatives including policy enactments. For instance, in terms of policy, Okpala (2011) remarked that for successful implementation, the Federal Government of Nigeria has promised that education should be tuition free, universal, and compulsory and that the STEM subjects should be taught to enable students to acquire further knowledge and skills. Youth clubs (e.g., Junior Engineers, Technicians, and Scientists clubs), organizations, and schools societies should be encouraged as important instruments for character training and mental development. Governments have also partnered with other stakeholders such as Airtel, SHELL Corporation, Huawei Technologies, and other national and multinational organizations for STEM development initiatives.

In spite of this commitment and benefits of STEM education, studies have reported inconsistent findings in connection with students' enrollments and performances in STEM subjects. For instance, the studies of Sakiyo and Badau (2015) and Ugo and Akpoghol (2016) found fluctuating students' performances in STEM subjects. Furthermore, Adeyemi (2011) in his comparative study of students' academic performance in public examinations in the Osun and Ekiti States of Nigeria found low student academic performance in mathematics and integrated science during the years under review. Further, Osuolale (2014) in his study on analysis of the problems of teaching and learning of science in Junior Secondary Schools in Nasarawa State of Nigeria found that students have a poor foundation in science. However, the studies of Maliki et al. (2017) revealed that students' performance in mathematics in Junior Secondary School examinations in Bayelsa, Nigeria, were high, favoring male students. In terms of enrollment, while the studies of Aderemi et al. (2013), Umoh (2016), and Sakiyo and Badau (2015) found increases in the enrollment of students in STEM subjects, the study of Ugo and Akpoghol (2016) found inconsistent enrollment of students in STEM subjects. Meanwhile, at the Upper Basic Education, which is the concern of this study, all subjects are compulsory. Therefore, the enrollment may be high because of the explosion in the enrollment figures of students in the Universal Basic Education (UBE) programme (Umoh, 2016).

Recently, large school enrollments have been one reason given by policymakers for the poor public school performance (Bullard, 2011). Although the study of Bullard (2011) found small but not substantive effect of enrollment size on average However, the study of Bullard (2011) revealed small but not significant effect of enrollment size on average student academic achievement which also concurs with the finding of Gershenson and Langbein (2015) that no causal relationship existed between school enrollment and students' academic performance. Contrarily, Bakasa (2011) reported that descriptive findings of her study, which are triangulation of the data gathered from the various instruments of data collection used, pointed toward a conclusion that class size and school factors such as teacher effectiveness can influence students' achievement.

Therefore, in view of the emphasis on the development of STEM-capable skills in students to make them fit into the increasingly changing complex society, conflicting findings on students' enrollment, and performances in STEM-related subjects coupled with the various governments initiative toward the production of STEM-compliant learners; this study investigated not only the trends of students' performance in STEM-related subjects in the Junior Secondary School examinations for 5 years (2011-2015) but also predicted what the performance would look like in another 5 years (2016-2020) with a view to suggesting possible solutions should the need arises from the findings of the study. The period of 2011-2015 was chosen not only because of popularity of STEM education during the period but also media report on improvement of students in STEM subjects in Upper Basic Level of Education, especially in Ogun State. To achieve this, the researchers adopted the disciplinary approach of investigating individual subjects that make up STEM. According to the National Policy on Education (FRN, 2013), they are Mathematics, Basic Science, Basic Technology, Information Technology, Physical, and Health Education. However, this study only analyzed the trend of students' performance in Basic Science, Basic Technology and Mathematics.

\section{Research Questions}

The study was guided by the following research questions:

1. What is the trend of enrollment of Junior Secondary School students in the STEM subjects of Basic Science, Basic Technology, and Mathematics in OG-BECE from 2011 to 2015 ?

2. What is the trend of Junior Secondary School students' performance in STEM subjects of Basic Science, Basic Technology, and Mathematics in OG-BECE from 2011 to 2015 ?

3. What is the failure trend of Junior Secondary School students in Basic Science, Basic Technology, and Mathematics in OG-BECE from 2011 to 2015 ?

4. What will be the pass trend of students in Basic Science, Basic Technology, and Mathematics in OG-BECE in the next 5 years, i.e., from 2016 to 2020 ?

\section{METHODOLOGY}

The study adopted an ex post facto research design to investigate the trend of students' performances in Basic Education Certificate Examinations (BECE) conducted by the Ogun State Ministry of Education, Science and Technology (OGMES and T) in the STEM subjects of Basic Science, Basic Technology, and Mathematics from 2011 to 2015. The 
design did not involve manipulation of the respondents and all the students that enrolled and sat for the examinations within the years under review constituted the target population. The results were obtained from OGMES \& $\mathrm{T}$, Department of Planning, Research, and Statistics and as such were assumed to be valid and reliable.

\section{Method of data analysis}

The collected students' performance results were analyzed using Microsoft Excel with its in-built trend line capabilities.

\section{RESULTS}

The analyses based on the research questions are, thus, presented:

Research Question 1: What is the trend of enrollment of Junior Secondary School students in the STEM subjects of Mathematics, Basic Science, and Basic Technology from 2011 to 2015 ?

Table 1 summarizes a steady increase in the number of students who sat for the BECE from 2011 to 2015. Enrollment in Mathematics witnessed the highest improvement with 72,283 candidates in 2011-97,461 in 2015, followed by Basic Science with 72,380 in 2011-72,380 in 2015. This was followed by Basic Technology with 69,214 in 2011-91,167 in 2015 (Figure 1).

Research Question 2: What is the trend of Junior Secondary School students' performance in STEM subjects of Mathematics, Basic Science, and Basic Technology from 2011 to 2015 ?

Figure 2 indicates inconsistent performance in all subjects. However, the table reveals that students' performances in mathematics yearly were improving steadily until 2015 when it dropped. The table also reveals that Basic Science and Basic Technology had their highest percentage performances in 2013 with $97.75 \%$ and $97.55 \%$, respectively; Mathematics had its peak performances in 2014 with $97.52 \%$ and lowest performance in 2015. Basic Science also had its lowest performance in 2015 with 94.94\%. In fact, 2015 was a year of students' least performance in all selected STEM subjects compared to the previous years.

Research Question 3: What is the trend of the failure of Junior Secondary School students in the STEM subjects of Basic Science, Basic Technology, and Mathematics from 2011 to $2015 ?$

Table 2 summarizes that the students' failure rates like their pass rates were not steady with Mathematics (7.87) and Basic Science (5.06) having its highest failure rate in 2015; Basic Technology (6.71) had its highest failure rate in 2011.

Research Question 4: What will be the trend of students' performance in Basic Science, Basic Technology, and Mathematics in the next 5 years?

Projecting from Figure 4, the students' performance in Basic Technology and Basic Science will continue to improve

\begin{tabular}{|c|c|c|c|}
\hline Years & Mathematics (\%) & Basic science (\%) & Basic technology (\%) \\
\hline 2011 & $72,283(92.92)$ & $72,380(96.62)$ & $69,214(94.70)$ \\
\hline 2012 & $79,993(94.04)$ & 79,961 (95.95) & 76,179 (94.57) \\
\hline 2013 & $89,355(97.42)$ & $89,183(97.75)$ & $85,239(97.55)$ \\
\hline 2014 & $94,480(97.52)$ & $94,188(97.16)$ & $89,588(96.46)$ \\
\hline 2015 & $97,461(92.41)$ & 96,797 (94.94) & 91,167 (94.13) \\
\hline
\end{tabular}

Source: Ogun State Ministry of Education, Science and Technology (2017)

\begin{tabular}{lccc}
\hline \multicolumn{4}{l}{ Table 2: Students' percentage failure rates per subject } \\
\hline Years & Mathematics & Basic Science & Basic Tech \\
\hline 2011 & 7.08 & 3.39 & 6.71 \\
2012 & 5.95 & 4.05 & 3.39 \\
2013 & 2.57 & 2.25 & 2.45 \\
2014 & 2.49 & 2.84 & 3.54 \\
2015 & 7.87 & 5.06 & 5.87 \\
\hline
\end{tabular}

steadily without fluctuation. However, the performances of students in Mathematics will start declining after 2015 and reach the lowest level of about 75\% in 2017. From 2018, the performances are predicted to improve until 2020. These predictions of the students' performances in the subjects were modeled by the following formulae:

$$
\begin{aligned}
& \mathrm{Y}_{\text {Mathematics }}=\mathrm{y}=0.4171 \mathrm{x}^{4}-3358.7 \mathrm{x}^{3}+1 \mathrm{E}+07 \mathrm{x}^{2}-1 \mathrm{E}+10 \mathrm{x}+7 \mathrm{E}+12 ; \\
& \mathrm{R}^{2}=1 \\
& \mathrm{Y}_{\text {Basic Science }}=\mathrm{y}=0.1504 \mathrm{x}^{4}-1211.8 \mathrm{x}^{3}+4 \mathrm{E}+06 \mathrm{x}^{2}-5 \mathrm{E}+09 \mathrm{x}+2 \mathrm{E}+12 ; \\
& \mathrm{R}^{2}=1 \\
& \begin{array}{c}
\text { Basic Technolog } \\
\mathrm{R}^{2}=1
\end{array}
\end{aligned}
$$

The value of the $\mathrm{R}^{2}$ is to ascertain the accuracy of the model. The $\mathrm{R}^{2}=1$ is a best fit because the closer the value of $\mathrm{R}^{2}$ to 1 , the better the line fits the data.

\section{DISCUSSION}

The study revealed that, during the years under review, there was a steady increase in the enrollment of candidates for the selected STEM subjects with Mathematics having the highest improvement, followed by Basic Science and then Basic Technology with good grades but associated with inconsistency in students' performances in these subjects. The findings of steady increase in students' enrollment in the selected STEM subjects are in consonance with the findings of Sakiyo and Badau (2015) and Umoh (2016) who found increased enrollment of students in STEM subjects but with fluctuating performance. This may be because the selected STEM subjects are compulsory for all students at that level of education in line with UBE policy and their experiences at this level will determine their future enrollment (McDonald, 2016). Presumably, it may also be as a result of government and major stakeholders' efforts in ensuring that students embrace STEM education for competitive advantages. 


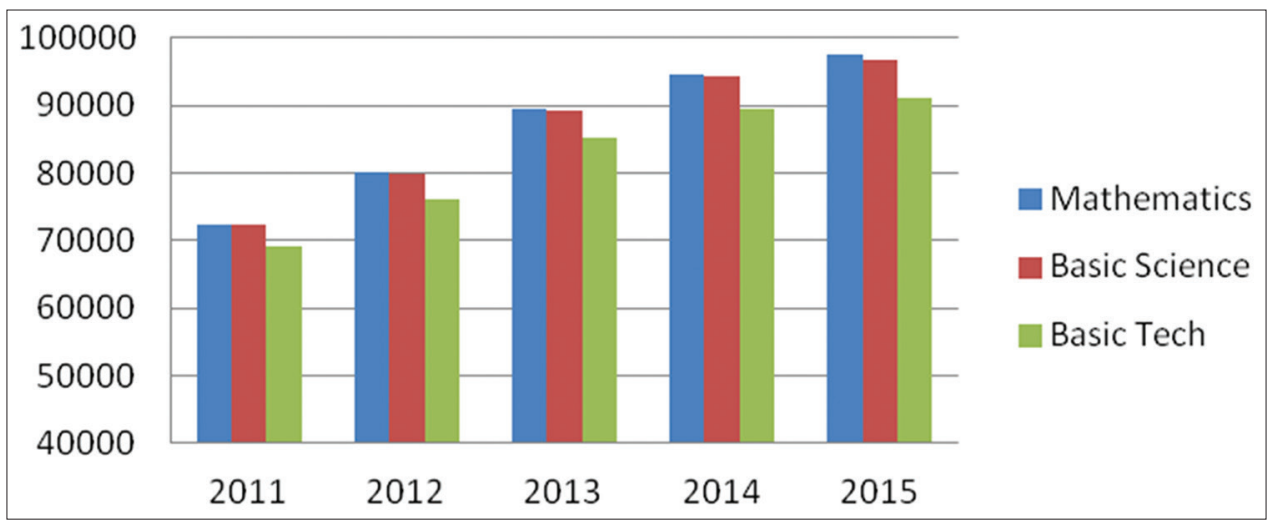

Figure 1: Bar chart showing the trend of enrollment of candidates for Mathematics, Basic Science, and Basic Technology in BECE from 2011 to 2015

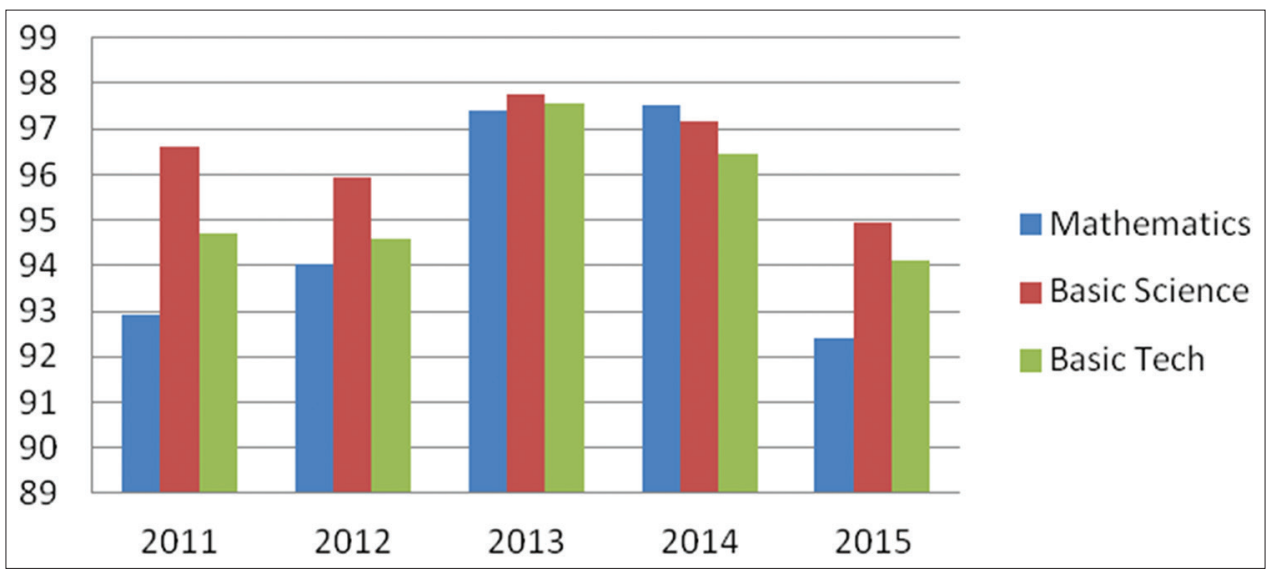

Figure 2: Bar chart showing the trend of academic performance of candidates that sat for Mathematics, Basic Science, and Basic Technology in BECE from 2011 to 2015

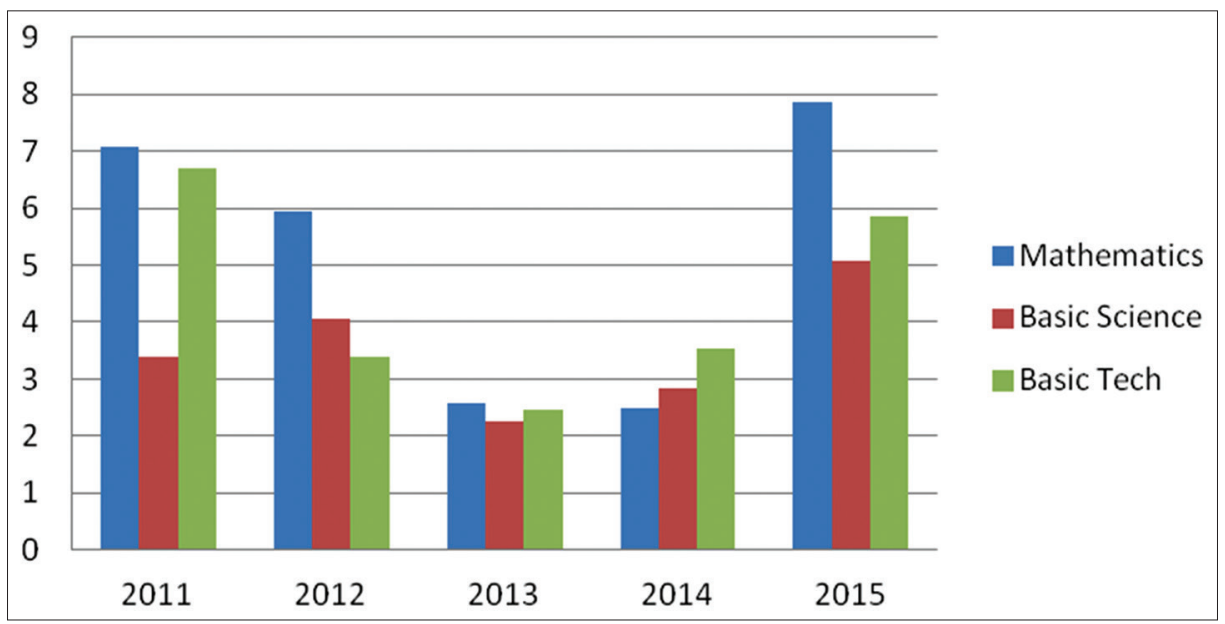

Figure 3: Bar chart showing the trend of failure of candidates that sat for Mathematics, Basic Science, and Basic Technology in BECE from 2011 to 2015

Figure 3 revealed that though the students were performing well in the selected STEM subjects in the years under review, the performances were fluctuating for all the subjects. Revealed that though the students were performing well in the selected STEM subjects in the years under review, the performances were fluctuating for all the subjects. For instance, students had their best performance in mathematics in 2014 with lowest performance in 2015. Other subjects investigated revealed similar trend with the least performances recorded in 2015 by all the subjects, though the differences did not suggest poor performances. The least performances of students in 2015 could be attributed to increase in enrollment of students into the Upper Basic Level of Education during the period. The increase in enrollment might have necessitated increase in class 


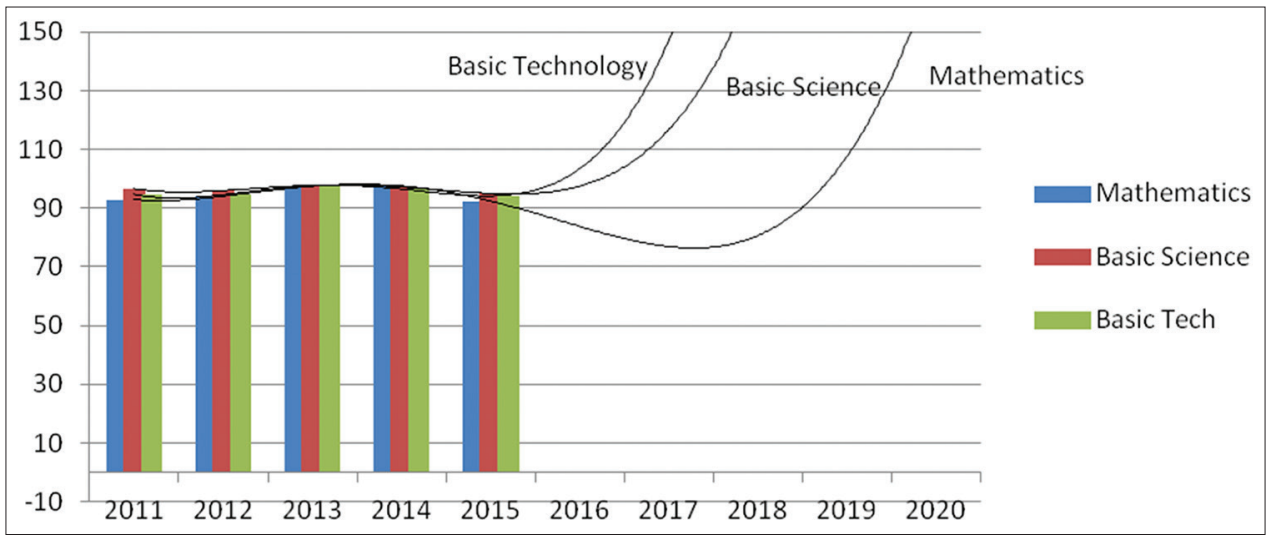

Figure 4: Chart showing the trend of students' performance in Science, Technology, Engineering, and Mathematics subjects of Mathematics, Basic Science, and Basic Technology in Basic Education Certificate Examination in the next 5 years (2016-2020)

size, which implies that the teachers might have more students to cater for than in the previous years. This finding of students' enrollment affecting students' performance supports the finding of Bakasa (2011) that class size can influence student achievement. It also corroborates the finding of Bullard (2011) which revealed small but not substantive effect of enrollment size on average student academic achievement.

The study further revealed that students' performances, in the years under review, in Mathematics, Basic Science, and Basic Technology though fluctuating were far above average (more than $70 \%$ ). The finding on good performance in mathematics specifically corroborates the finding of Maliki et al. (2017) which revealed high students' performance in Mathematics in Junior Secondary schools in Bayelsa. The findings on good performance in mathematics and other selected subjects are, however, contrary to the studies of Adeyemi (2011) which revealed low students' performance in Mathematics and Integrated Science (Basic Science and Basic Technology) and that of Osuolale (2014) which revealed students' poor foundation in science.

While the findings of this study predicted that students' performance in Basic Science and Basic Technology would continue to improve steadily without fluctuation in the next 5 years (2016-2020), students' performance in mathematics was predicted to start declining after 2015 and reach the lowest level in 2017 and then begin to improve until 2020. The finding on mathematics may be attributed to likely future increase in enrollment of students into Upper Basic Level of Education due to efforts of government and other stakeholders toward the realization of the goals of STEM education. Since mathematics is compulsory for all learners at this level of education, increase in enrollment may affect the performance. This may also be attributed to the fact that students do not appreciate the interrelatedness of mathematics with other STEM subjects because in Nigeria they are taught in a disjointed manner contrary to the advocacies that it should be taught in multidisciplinary manner to enable the students appreciate interconnectedness and how the skills acquired could be used in the real world (NGGS, 2013; Matazu and
Julius, 2017). This finding contradicts the submission of English (2015) that STEM education concentrated heavily on science and mathematics at the expense of the critical roles of engineering and technology in preparing students to participate in an increasingly digital world. If concentration is on Mathematics and Science as submitted by the researcher, the prediction should have favored Mathematics more than Basic Technology. The improved performance recorded by students in Basic Science and Basic Technology between 2011 and 2015 and similar trend predicted for the subjects from 2016 to 2020, respectively, may be due to the acceptance of STEM subjects as those that will give them the skills, which will enable them to live and contribute positively to the society in which they live. In addition, it may be due partially to the rapid technological and scientific development being witnessed in all areas of human endeavors, which has permeated to the grassroots globally.

\section{CONCLUSION}

The improved enrollment and students' good performance though not steady is a mark that students are beginning to appreciate the values of science and technology in solving the problems of the society. It is also an attestation that various governments' and stakeholders' efforts in promoting STEM education at all tiers of education are encouraging and motivating. However, from the data collected, it was observed that teaching and learning of these subjects have been on a disjointed manner (stand-alone) which is contrary to goals of STEM education that the subjects should be integrated. This may, thus, account for reason the students do not see the relationship among the different subjects that make up the STEM education. Therefore, if such pattern of teaching and learning the STEM subjects continues, Nigeria learners may not gain substantially from the benefits accruable from effective STEM education.

\section{RECOMMENDATIONS}

Based on the findings of this study, the following recommendations are provided: 
1. Government should continue to support STEM education in all tiers of education by fulfilling all necessary obligations that will facilitate the teaching and learning of the STEM subjects with the intention of building and sustaining students' interest to train and become great scientists, engineers, and mathematicians. This will ensure continual good performance of students in the subjects.

2. Teachers should strive to teach STEM subjects in an integrative manner to enable students to see interrelationships between them and to foster acquisition of scientific knowledge and skills, which can be used for national growth and development.

\section{REFERENCES}

Aderemi, H.O., Hassan, O.M., Siyanbola, W.O., \& Taiwo, K. (2013). Trends in enrolment, graduation and staffing of science and technology education in Nigeria tertiary institutions: A gender participation perspective. Education Research and Reviews, 8(2), 2011-2020. Available from: https://www.eric.ed.gov/?id=EJ1017573. [Last retrieved on $2018 \mathrm{Feb} 04]$.

Adeyemi, T.O. (2011). A comparative study of students' academic performance in public examinations in secondary schools in Ondo and Ekiti States, Nigeria. Journal of Economic Theory, 3(2), 36-42.

Adikwu, M. U. (2012). Curriculum Development in Science, Technology and Mathematics (STM) Education. A Keynote Address presented at the $49^{\text {th }}$ Annual Conference of Science Teachers Association of Nigeria, Yenagoa.

Ainley, J., Kos, J., \& Nicholas, M. (2008). Participation in Science, Mathematics and Technology in Australian Education (ACER Research Monograph 63). Camberwell: The Australian Council for Educational Research.

Bakasa, L. (2011). Effect of Class Size on Academic Achievement at a Selected Institution of Higher Learning. (Master Thesis, University of South Africa). Available from: http://www.uir.unisa.ac.za/bitstream/ handle/10500/5759/thesis_bakasa_l.pdf?sequence $=1 \&$ isAllowed $=y$. [Last retrieved on $2018 \mathrm{Apr} 12$ ].

Barnett, R., \& Coat, K. (2005). Supercomplexity and the Curriculum in Higher Education. Buckingham, UK: Open University Press, McGraw Hill Education.

Bullard, H.C. (2011). The Effects of School Enrolment Size on Student Achievement. (Master Thesis, the Faculty of the Graduate School of Arts and Sciences, Georgetown University). Available from: https://www. repository.library.georgetown.edu/bitstream/handle/10822/553670/ bullardHolly.pdf;sequence $=1$. [Last retrieved on 2018 Apr 13].

Comino, S. (2017). 5 Reasons why STEM is important in early years of Education. Retrieved $15^{\text {th }}$ October, 2017 from www.tsc.now.edu.au.

English, L. D. (2015). STEM: Challenges and opportunities for Mathematics Education. In: Proceedings of the $39^{\text {th }}$ Conference of the International Group for the Psychology of Mathematics Education Research (J-PEER). p5.

European University Association. (2007). Creativity in Higher Education: Report on the UEA Creativity Project 2006-2007. Available from: https://www.eua.be/fileadmin/use_upload/files/Publications/Creativity_ in_higher_education.pdf. [Last retrieved on $2018 \mathrm{Feb}$ 15].

Federal Republic of Nigeria. (2013). National Policy on Education. Lagos: NERDC Press.

Florida Department of Education (FDE). (2017). Defining STEM. Available from: http://www.fldoe.org. [Last retrieved on 2017 Oct 15].

Gershenson, S., \& Langbein, L. (2015). The effect of primary school size on academic achievement. Educational Evaluation and Policy Analysis, 37(1), 135-155. Available from: http://www.journals.sagepub.com/doi/ pdf/10.3102/0162373715576075. [Last retrieved on 2018 Apr 13].

Igboanugo, B.I., \& Egolum, E.O. (2017). Strategies for Making STM Education Accessible to All Citizens. In: $60^{\text {th }}$ Anniversary Conference Proceedings, $14^{\text {th }}-19^{\text {th }}$-August, 2017. Science Teachers Association. p8-12.

Jackson, N. (2005). Making higher education a more creative place. Journal for the Enhancement of Learning and Teaching, 2(1), 14-25. Available from: http://www.uhra.herts.ac.uk/bitstream/handle/2299/2595/902905. pdf; sequence $=1$. [Last retrieved on 2017 Dec 26].

Maliki, A.E., Ngban, A.N., \& Ibu, J.E. (2009). Analysis of students' performance in junior secondary school mathematics examinations in bayelsa State of Nigeria. Journal of Studies in Home and Community Science, 3(2), 131-134.

Matazu, S.S., \& Julius, E. (2017). Enhancing Entrepreneurial Skills in STEM Education for Socio-economic Empowerment among Secondary School. In: $60^{\text {th }}$ Anniversary Conference Proceedings, $14^{\text {th }}-19^{\text {th }}$-August. Science Teachers Association of Nigeria. p46-50.

McDonald, C.V. (2016). STEM education: A review of the contribution of the disciplines of science, technology, engineering and mathematics. Science Education International, 27(4), 530-569.

National Research Council (NRC). (2014). STEM Integration in K-12 Education Status. Washington DC: The National Academic Press.

Ndinechi, M.C., \& Okafor, K.C. (2016). STEM Education: A Tool for Sustainable National Capacity Building in a Digital Economy. Available from: https://www.researchgates.net/publication/303446505. [Last retrieved on 2018 Jan 26].

Next Generation Science Standards (NGSS). (2013). For States, by States. Vol. 2. Washington, DC: Achieve Press Inc.

Obomanu, B.J., \& Adaramola, M.O. (2011). Factors related to underachievement in science, technology and mathematics education (STME) in secondary school in rivers state, Nigeria. World Journal of Education, 1(1), 102-109.

Ogun State Ministry of Education, Science and Technology. (2017). Enrolment and Percentage Pass Rates Per Subject. Abeokuta. Nigeria: Department of Planning, Research and Statistics.

Okpala, P.N. (2011). Reforms in Science, Technology, Engineering and Mathematics (STEM) Education. Available from: http://www.stanonline. org/NIGERIAN\%20STEM\%20EDUCATION\%20REFORMS.pdf. [Last retrieved on 2018 Jan 10].

Osuolale, O.J. (2014). Problems of teaching and learning science in junior secondary schools in Nasarawa State, Nigeria. Journal of Education and Practice, 5(3), 109-118.

Portz, S. (2015). The challenges of STEM Education. The Space Congress Proceedings, Paper 3. Available from: http://www.commons.erau/ space-congress-proceedings/proceeding-2015-43rd/proceedings-201543rd/13. [Last retrieved on $2018 \mathrm{Feb} 2]$.

Sakiyo, J., \& Badau, K.M. (2015). Assessment of the trend of secondary school students' academic performance in Sciences, Mathematics and English: Implication for the attainment of the millennium development Goals in Nigeria. Advances in Social Sciences Research Journal, 2(2), 31-38.

Salau, A. (2017). STEM is Critical in Propelling Nigeria and Africa to Greatness. Available from: https://www.opinion.premiumtimes. ng.com/2017/02/16/stem-is-critical-in-propelling-Nigeria-and-Africato-greatness-by-adetola-salau/. [Last retrieved on 2017 Nov 23].

Science Ambassadors Foundation (SAF). (2014). STEM Education: The Tool Addressing the Gap. Available from: http://www.scienceambassadors. org.ng. [Last retrieved on $2018 \mathrm{Feb} 12]$.

Shameema, P., \& Christian, B. (2017). Why is STEM Education Important? Available from: http://www.gessdubai.com. [Last retrieved on 2018 Jan 17].

Ugo, E.A., \& Akpoghol, T.V. (2016). Improving science, technology, engineering and mathematics (STEM) programs in Secondary schools in Benue State, Nigeria: Challenges and prospects. Asia Pacific Journal Education, Arts and Sciences, 3(3), 6-16. Available from: http:// www.oaji.net/articles/2016/1710-1475121311.pdf. [Last retrieved on 2018 Jan 25].

Umoh, S.W. (2016). Problems and prospects of effective science, technology and mathematics (STEM) education delivery in Nigeria. Knowledge Review, 35(1), 1-5.

United Nations Educational, Scientific and Cultural Organization (UNESCO). (2016). Closing the Gender Gap in STEM: Drawing More Girls and Women into Science, Technology, Engineering, Mathematics. Available from: http://www.unesdoc.unesco.org. [Last retrieved on 2018 Jan 31]. 